\title{
Peningkatan Keterampilan Berbicara dengan Metode Bermain Peran Pada Siswa
}

\author{
Anugerah Husada*1, Mei Fita Asri Untari² $^{2}$ Ahmad Nashir Tsalatsa ${ }^{3}$ \\ 1,2,3 Universitas PGRI Semarang
}

A R T I C L E I N F O

Article history:

Received 19 February

2019

Received in revised form

30 March 2019

Accepted 10April 2019

Available online 20 May

2019

Kata Kunci:

Bermain peran,

kemampuan berbicara

Keywords:

Role playing, speaking ability

\begin{abstract}
A B S T R A K
Tujuan yang hendak dalam penelitian ini adalah 1) Meningkatkan keterampilan guru dalam pembelajaran bahasa Indonesia dengan menggunakan metode bermain peran, 2) Meningkatkan aktivitas belajar peserta didik dengan pembelajran bahasa indonesia dengan metode bermain peran, 3) Meningkatkan hasil belajar peserta didik dalam pembelajaran bahasa indonesia dengan menggunakan metode bermain peran. Jenis penelitian ini adalah penelitian tindakan. Subjek penelitian adalah guru dan seluruh peserta didik kelas IV SDN 02 Gidangelo tahun pelajaran 2018/2019. Sampel yang diambil adalah 29 peserta didik kelas IV dengan menggunakan data dalam penelitian ini diperoleh melalui tes, observasi, dan dokumentasi. Dari hasil penelitian diketahui bahwa terdapat peningkatan perolehan nilai keterampilan berbicara. Pada pratindakan nilai rata-rata 65,80 dan jumlah ketuntasan peserta didik sebesar $31 \%$. Lalu pada siklus I diterapkan metode bermain peran memperoleh nilai rata-rata 75,86 dan jumlah ketuntasan peserta didik sebesar $62 \%$. Artinya, penggunaan metode Bermain Peran dapat meningkatkan kemampuan berbicara peserta didik, akan tetapi hasil yang diperoleh belum melampaui target yang ditentukan peneliti sehingga dilanjutkan pada siklus II. Pada siklus II memperoleh nilai ratarata 84,77 dan jumalh ketuntasan peserta didik sebesar $72 \%$. Kesimpulannya bahwa metode Bermain Peran dapat meningkatkan kemampuan berbicara peserta didik.
\end{abstract}

A B S T R A C T

The objectives of this research are 1) Increasing teacher skills in learning Indonesian by using role playing methods, 2) Increasing learning activities of students by learning Indonesian with role playing methods, 3) Improving student learning outcomes in Indonesian learning with using the role playing method. This type of research is action research. The research subjects were teachers and all fourth grade students of SDN 02 Gidangelo 2018/2019 academic year. The samples taken were 29 fourth grade students using data in this study obtained through tests, observations, and documentation. The results of the study revealed that there was an increase in the acquisition of the value of speaking skills. In pratindakan the average value of 65.80 and the number of students completeness by $31 \%$. Then in the first cycle applied the role playing method obtained an average value of 75.86 and the total completeness of students was $62 \%$. That is, the use of the Role Playing method can improve the speaking ability of students, but the results obtained have not exceeded the target determined by the researcher so that it is continued in the second cycle. In the second cycle, the average score of 84.77 and the total completeness of students was $72 \%$. In conclusion, the Role Playing method can improve students' speaking abilities. 


\section{Pendahuluan}

Berdasarkan UU No. 20 Tahun 2003, tentang sistem pendidikan nasional, pendidikan adalah usaha sadar dan terencana untuk mewujudkan suasana belajar dan proses pembelajaran agar peserta didik secara aktif mengembangkan potensi dirinya untuk memiliki kekuatan spiritual keagamaan, pengendalian diri, kepribadian, kecerdasan, ahklak mulia, serta ketrampilan yang diperlukan dirinya, masyarakat, bangsa dan Negara. Pentingnya pendidikan di era global ini sangat menunjang kesejahteraan masyarakat. Karena itulah pendidikan merupakan kebutuhan pokok yang harus dirasakan seluruh masyarakat baik itu kelas bawah, menengah, maupun atas.

Guru dituntut untuk memiliki berbagai kecakapan dalam proses pembelajaran sehingga tujuan pembelajaran dapat tercapai dengan baik. Guru sebagai pelaksana pendidikan formal yang berperan besar bagi keberlangsungan proses pendidikan selanjutnya. Pendidikan bertujuan untuk menciptakan individu yang berkuslitas dan berkarakter yang memiliki padangan luas ke depan untuk mencapai cita-cita yang diharapkan.

Sesuai dengan kurikilum 2013 dan sejalan yang di amanatkan di UU No. 20 Tahun 2003 maka yang harus menjadi focus utama dalam kurikulum yaitu proses belajar mengajar ataupun pengalaman belajar yang di susun dengan memaksukkan aspek-aspek seperti interaksi social, lingkungan sekolah, ataupun kerjasama dengan kelompok. Namun secara umum tujuan pendidikan dalam kurikulum 2013 tidak jauh beda dengan kurikulum sebelumnya. Artinya guru sebagai pelaksana pembelajaran harus melaksanakan pembelajaran secara terencana sehingga terwujud suasana belajar dan proses pembelajaran dimana guru berfungsi sebagai fasilitator yang memungkinkan pembelajaran secara berkelompok.

Keterampilan berbicara sebagai salah satu keterampilan berbahasa yang perlu dimiliki dan dikuasai dengan baik oleh peserta didik SD agar mampu berkomunikasi secara lisan. Oleh karena itu, peranan pengajaran Bahasa Indonesia khususnya pengajaran berbicara di SD menjadi sangat penting. Pengajaran Bahasa Indonesia di SD yang bertumpu pada kemampuan dasar berbicara dan menulis juga perlu diarahkan pada tercapainya kemampuan berbicara peserta didik dengan baik. Keterampilan berbicara dan menulis, khususnya keterampilan berbicara harus segera dikuasai oleh para peserta didik di SD karena keterampilan ini secara langsung berkaitan dengan seluruh proses belajar peserta didik di SD. Keberhasilan belajar peserta didik dalam mengikuti proses kegiatan belajar mengajar di sekolah sangat ditentukan oleh penguasaan kemampuan berbicara mereka. Dalam pembelajaran di sekolah, keterampilan berbicara diperlukan sebagai alat menyatakan pendapat, memberi informasi atau menerima informasi (Ningsih, 2014).

Metode bermain peran atau teknik pengajaran adalah suatu cara penguasaan pelajaran kegiatan pengembangan imajinasi penghayatan suatu tokoh tertentu. Bermain peran adalah model pembelajaran melalui pemeranan sebuah situasi dalam hidup manusia dengan tanpa diadakan latihan untuk mencapai tujuan bersama dalam rangka mencari penyelesaian dari suatu masalah yang sering dihadapi siswa dalam kehidupan seharihari dan dapat digunakan untuk mendiagnosis dan mengerti seseorang, sebagai media pengajaran dan metode pelatihan ketrampilan tertentu (Wicaksono, 2013). Bermain peran dikenal juga dengan sebutan bermain pura-pura, khayalan, fantasi, make belive, atau simbolik (Siska, 2011). Saat bermain peran dibuatkan pembagian peran dan deskripsi setiap peran, selebihnya para pemain melakukan improvisasi untuk mengembangkan perannya masing-masing (Febrisma, 2013). Tarigan dkk (1991 : 389), teknik bermain peran sangat baik dalam mendidik peserta didik untuk menggunakan ragamragam bahasa. Bermain peran dapat dilakukan dalam berbagai macam peranan, seseorang dapat memerankan berbagai peran dalam satu harinya, misalnya sebagai seorang ibu, istri, teman, kepala sekolah, penjual, pembeli, dan sebagainya.

Pada setiap peranan tersebut seorang anak harus dapat berperilaku sesuai dengan peran yang dilakukannya. Melalui bermain peran, peserta didik mencoba mengeksploitasi masalah-masalah hubungan antarmanusia dengan cara memperagakannya (Pranowo, 2013). Cara anak berperilaku pada setiap peranan tersebut bergantung pada status atau posisinya dengan pasangan perannya. Jadi, perilaku ibu kepada anaknya berbeda dengan perilaku terhadap suaminya dan berbeda pula dengan bawahannya di sekolah. Cara berbicara orang tua tentu berbeda dengan cara berbicara anak muda, cara berbicara pembeli tentu berbeda dengan cara berbica penjual. Fungsi dan peranan seseorang menuntut cara berbicara atau berbahasa tertentu pula. Tarigan dkk (1991 : 389). Dalam bermain peran, siwa bertindak, berperilaku, dan berbahasa sesuai dengan peranan tokoh yang diperankannya. Misalnya sebagai guru, polisi, hakim, dokter, pedagang, dan sebagainya. Setiap tokoh tertentu menuntut karakteristik tertentu pula. Dengan kata lain kepribadian seseorang adalah keseluruhan peranan yang diperankannya dalam kehidupan sehari-hari di lingkungan keluarganya, masyarakat, dan pekerja sekalipun. Seseorang dapat dikatakan mempunyai penyesuaian diri yang baik apabila dapat berperilaku sesuai dengan peranan yang dimilikinya baik sebagai individu maupun mahkluk social. Berdasarkan hasil wawancara dan pengamatan 
yang dilakukan peneliti di kelas IV SDN 02 Gidangelo Kecamatan Welahan Kabupaten Jepara, dalam pembelajaran Bahasa Indonesia ternyata masih banyak peserta didik yang belum lancar dalam berbicara atau bercerita, ada beberapa peserta didik yang masih terbata-bata berbicara di depan kelas, juga terdapat tiga peserta didik yang tidak mau maju ke depan kelas untuk bercerita, dan secara umum peserta didik bercerita di depan kelas dengan intonasi yang datar dan tanpa ekspresi. Berdasarkan pengamatan di hari yang sama peneliti menemukan beberapa peserta didik yang sama sekali tidak mau maju dan di lihat dari ekspresinya peserta didik tersebut terlihat mau menangis, sebagian besar peserta didik sudah mau maju bercerita namun hasilnya masih belum runtun dan belum menggunakan intonasi dan ekspresi yang baik untuk bercerita.

Berdasarkan studi dokumentasi untuk pembelajaran Bahasa Indonesia aspek membaca dialog yang di dapatkan dari buku nilai, dari 29 jumlah peserta didik ternyata yang mengalami ketuntasan hanyalah 9 peserta didik. Berarti terdapat $31 \%$ peserta didik yang memperoleh ketuntasan dalam mengikuti pembelajaran Bahasa Indonesia materi berbicara. Nilai tertinggi yang diperoleh peserta didik adalah 100, sedangkan nilai terendah adalah 33. Adapun perolehan nilai rata-rata kelas hanya 65,80 . Hasil tersebut sudah sedikit melampaui dari KKM yaitu 70 .

Faktor-faktor tersebut di atas, satu yang paling mendesak untuk dipecahkan adalah kurangnya perhatian peserta didik terhadap materi bahasa indonesia yang disampaikan guru. Alasan mengapa faktor tersebut sangat mendesak untuk dipecahkan adalah jika dicermati tersirat beberapa faktor, antara lain peserta didik kurang memperhatikan guru, materi yang disampaikan kurang menarik, dan cara guru menyampaikan pelajaran sangat berpengaruh terhadap hasil belajar peserta didik.

Peneliti memilih metode pembelajaran bermain peran sebagai alternatif untuk pembaharuan kegiatan pembelajaran Bahasa Indonesia di kelas IV SDN 02 Gidangelo. Peneliti menggunakan metode bermain peran untuk diterapkan guru pada saat pembelajaran. Alasan peneliti menggunakan metode bermain peran karena dengan menggunakan metode tersebut peserta didik dapat lebih aktif dalam pembelajaran, peserta didik dilatih untuk berekspresi dan melatih keberanian peserta didik sehingga hasil belajar peserta didik dapat meningkat.

\section{Metode}

Penelitian tindakan kelas ini dilaksanakan di SDN 02 Gidangelo Kecamatan Welahan Kabupaten Jepara pada semester genap tahun pelajaran 2018/2019 pada kelas IV. Metode yang digunakan untuk meningkatan kemampuan berbicara siswa adalah metode bermain peran pada pelajaran bahasa Indonesia dengan menggunakan penelitian tindakan kelas.

Dalam penelitian ini peneliti merancang penelitian dalam dua siklus. Setiap siklus terdapat empat tahapan yaitu perencanaan, tindakan, observasi, dan refleksi. Tahapan tersebut disusun di dalam siklus dan setiap siklus dilaksanakan sesuai dengan perubahan atau target yang ingin dicapai. Maka peneliti bermaksud untuk menggunakan pertemuan pertama untuk melihat nilai peserta didik dan dilanjutkan untuk penelitian Siklus I dengan menerapkan metode bermain peran pada pembelajaran Bahasa Indonesia. Dan pertemuan terakhir digunakan peneliti untuk melakukan penelitian Siklus II menggunakan metode bermain peran dalam pembelajaran dengan memperbaiki dan menyempurnakan pada tindakan sebelumnya. Instrument penelitian peserta didik adalah alat atau fasilitas yang digunakan oleh peneliti dalam mengumpulkan data agar pekerjaannya lebih mudah dan mendapatkan hasil yang baik, dalam kata lain lebih cermat, lengkap, dan sistematis sehingga lebih mudah diolah (Suharsimi Arikunto, 2010:136). Instrument yang digunakan dalam penelitian tindakan kelas ini adalah :

a. Silabus

Silabus merupakan alat acuan untuk penyusunan kerangka pembelajaran untuk setiap bahan kajian mata pelajaran. Silabus dikembangkan berdasarkan Standar Kompetensi dan Standar Isi untuk satuan dasar pendidikan dasar dan menengah sesuai dengan pola pembelajaran pada setiap tahun ajaran tertentu. Silabus digunakan sebagai acuan dalam pengembangan rencana pelaksanaan pembelajaran (Permendiknas nomor 41 tahun 2007 tentang standar proses)

b. Rencana Pelaksanaan Pembelajaran

Rencana Pelaksanaan Pembelajaran (RPP) adalah rencana kegiatan pembelajaran tatatp muka untuk satu pertemuan atau lebih. RPP dikembangkan dari silabus untuk mengarahkan kegiatan pembelajaran peserta didik dalam upaya mencapai Kompetensi Dasar. RPP digunalan sebagai pedoman guru untuk mengajar. Komponen RPP berisi identitas mata pelajaran, standar kompetensi, kompetensi dasar, indikator pembelajaran, tujuan, materi ajar, alokasi waktu, metode pembelajaran, kegiatan pembelajaran, penilaian hasil belajar, dan sumber belajar. (Permendiknas nomor 41 tahun 2007 tentang standar proses). 
c. Lembar Kerja Peserta Didik

Lembar Kerja Peserta didik (LKS) merupakan salah satu sarana untuk membantu dan mempermudah dalam kegiatan belajar mengajar sehingga akan terbentuk interaksi yang aktif antara peserta didik dengan guru, sehingga dapat meningkatkan peserta didik dalam peningkatan hasil belajar.

d. Lembar Observasi

Lembar Observasi merupakan lembar kerja yang berfungsi untuk mengobservasi dan mengukur tingkat keberhasilan atau ketercapaian tujuan pembelajaran pada kegiatan belajar mengajar di kelas. Lembar pengamatan untuk peserta didik digunakan untuk mengamati keaktifan peserta didik saat kegiatan berlangsung.

Untuk memperoleh data dan dan informasi yang berkaitan dengan masalah yang dikaji dipakailah metode pengumpulan data dengan berbagai cara, yaitu melalui observasi, dokumentasi dan tes hasil belajar. Ketiga instrumen tersebut diuraikan sebagai berikut:

a. Observasi

Menurut Arikunto (2010:199) dalam pengertian psikologik, observasi atau disebut pula dengan pengamatan, meliputi kegiatan pemusatan perhatian terhadap suatu obyek dengan menggunakan seluruhh alat indra. Data observasi kelas diperoleh dari obsevasi motivasi peserta didik.pengambilan data dilakukan dengan cara memberikan nilai sesuai penilaian pengamatan yang dilakukan dari awal sampai akhir pembelajaran.

b. Dokumentasi

Dokumentasi merupakan cara pengumpulan data yang berupa catatan penting yang berhubungan dengan masalah yang diteliti. Menurut Arikunto (2002:206), metode dokumentasi adalah mencari data mengenai hal-hal atau variabel berupa catatan lapangan, notulen rapat, aktivitas peserta didik yang berlangsung dan sebagainya. Dokumentasi ini dilakukan dengan cara memotret dan merekam proses pembelajaran menggunakan HandPhone. Hasil dokumentasi diharapkan dapat dipakai sebagai pedoman bagi penelitian lanjutan atau disebarluaskan kepada guru lain sebagai metode baru di dalam pembelajaran.

c. Tes

Menurut Arikunto (2010:199) berpendapat bahwa tes adalah pertanyaan atau latihan serta alat lain yang digunakan untuk mengukur ketrampilan, pengetahuan intelegensi, kemampuan bakat yang dimiliki oleh setiap individu atau kelompok. Metode ini dilakukan untuk memperoleh data hasil belajar kognitif dalam pembelajaran tematik integrative dengan menggunakan metode bermain peran. Data hasil belajar peserta didik diperoleh dari hasil evaluasi akhir siklus.

Analisis data dalam setiap siklus yang terdapat pada penelitian tindakan kelas bertujuan untuk mengetahui hasil pada pembelajaran, apakah terjdi peningkatan selama tindakan berlangsung dan menyelesaikan sesuai target yang peneliti sudah tetapkan. Berikut adalah rumus yang digunakan untuk mencari presentase pada tiap aktifitas tindakan untuk mengetahui tingkat keberhasilan pada tindakan penelitian kelas (Anas Sudijono 2008: 43).

\section{$\mathbf{P} \frac{\mathbf{F}}{\mathrm{N}} \times 100$}

Keterangan:

$\mathrm{F}=$ Frekuensi yang dicari presentasinya

$\mathrm{N}=$ Number of Cases (jumlah frekuensi atau banyaknya individu)

$\mathrm{P}=$ Angka persentase

a. Analisis Hasil Belajar

Analisis hasil belajar peserta didik dilakukan untuk mengetahui hasil belajar berup kemampuan kognitif peserta didik dalam memecahkan masalah berupa mengerjakan soal tes evaluasi dengan cara menghitung ketuntasan belajar.

b. Analisis Lembar Observasi

Data motivasi diambil dari lembar observasi motivasi belajar, data tersebut diambil berdasarkan Teori ARCS Keller (1983) dalam Siregar (2011:52-53). Objek yang diamati antara lain adalah Attention (perhatian), Relevence (relevensi), Confidence (kepercayaan diri), dan Satisfaction (kepuasan). Dari empat objek pengamatan motivasi tersebut kemudian dijabarkan lagi menjadi 
beberapa aspek dengan kategori skor sebagai berikut (4) Sangat Termotivasi, (3) Termotivasi, (2) Cukup termotivasi, (1) kurang Termotivasi.

\section{Hasil dan Pembahasan}

Tabel 1. Peningkatan Hasil Pratindakan, Siklus I, dan Siklus II

\begin{tabular}{llll}
\hline Keterangan & Pratindakan & Siklus I & Siklus II \\
\hline Jumlah Skor & 229 & 264 & 295 \\
Nilai Rata - Rata & 65,80 & 75,86 & 84,77 \\
Ketuntasan Belajar & $31 \%$ & $62 \%$ & $72 \%$ \\
\hline
\end{tabular}

Sumber: Data Hasil Penelitian 2018

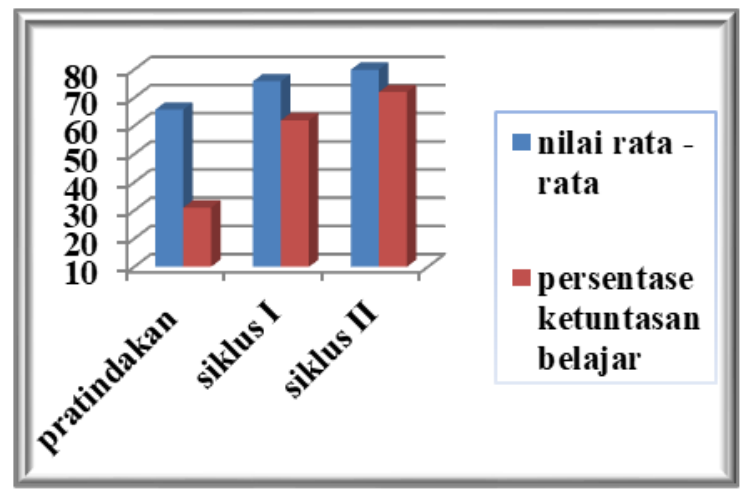

Gambar 1 Diagram Peningkatan Kemampuan Berbicara Melalui Metode Bermain Peran pada Aktifitas Pratindakan dan Siklus II.

Pada kegiatan pembelajaran Pratindakan diperoleh nilai rata - rata 65,80 dari keseluruhan jumlah peserta didik yang ada dan masih belum mencapai batas KKM yang ditentukan. Pada tindakan Siklus I yang telah diterapkan metode bermain peran untuk meningkatkan kemampuan berbicara peserta didik memperoleh nilai rata - rata sebesar 75,86. Pada tindakan Silkus I mengalami peningkatan hasil rata rata nilai jika dibandingkan dengan aktifitas Pratindakan sebesar 10,06\%. Pada kegiatan tersebut masih banyak kendala yang dialami dan masih banyak peserta didik yang masih belum memperoleh ketuntasan serta masih banyak peserta didik yang pasif dan kurang aktif dalam kegiatan pembelajaran.

Kegiatan tindakan pada Siklus II merupanakan perbaikan pada tindakan Siklus I yang sebelumnya sudah terlebih dahulu dilaksanakan. Kegiatan pada Siklus II bertujuan untuk memperbaiki kekurangan yang masih ada pada Siklus I untuk memenuhi target yang sebelumnya sudah ditentukan oleh peneliti.

Kegiatan Siklus II mengalami peningkatan kemampuan berbicara menggunakan metode bermain peran yang sangat baik jika dibandingkan dengan kemampuan berbicara pada Pratindakan. Selain hal tersebut peserta didik juga merasa senang, antusias, dan aktif dalam kemampusan berbicara pada kegiatan pembelajaran. Hasil tindakan Siklus II mengalami peningkatan nilai rata - rata sebesar 84,77 dari keseluruhan jumlah peserta didik. Dan jika dibandingkan dengan tindakan Siklus I dengan nilai rata - rata 75,86 maka mengalami peningkatan kemampuan berbicara sebesar 8,91\%. Hal tersebut dapat terjadi karena selama proses pelaksanaan Siklus II guru lebih melakukan pendekatan dan motivasi kepada para peserta didik yang memperoleh hasil kurang baik pada siklus sebelumnya, selain itu guru juga melakukan pendekatan kepada para peserta didiknya agar berani untuk bertanya apabila ada hal yang dirasa kurang mengerti dan memotivasi para peserta didiknya untuk jujur dan percaya diri dalam mengerjakan evaluasi serta berani maju ke depan kelas menyampai hasil pekerjaannya. Berdasarkan hasil perolehan nilai dan peningkatan nilai rata - rata yang diperoleh maka metode bermain peran dapat meningkatkan keterampilan berbicara pada peserta didik kelas IV SDN 02 Gidangelo.

\section{Simpulan Dan Saran}

Berdasarkan hasil penelitian dapat disimpulkan penerapan metode bermain peran dapat meningkatkan kemampuan berbicara peserta didik pada pembelajaran Bahasa Indonesia peserta didik kelas IV SDN 02 Gidangelo. Hal tersebut dapat dilihat melalui hasil observasi tindakan tiap Siklus 
mengalami peningkatan dan menunjukkan terjadi perubahan aktivitas peserta didik kea rah yang lebih aktif sehingga proses pembelajaran menjadi lebih baik dan menyenangkan bagi para peserta didik.

Peningkatan kemampuan berbicara peserta didik dapat dibuktikan dengan adanya peningkatan rata - rata hasil dari tiap tindakan Siklus dan sebelum tindakan atau Pratindakan. Pada saat Pratindakan $65,80 \%$, lalu setelah dilakukan tindakan pada Siklus I meningkat menjadi 75,86\%, dan setelah mengamati mengenai adanya keterbatasan dan kekurangan peneliti melakukan tindakan Siklus II untuk menyempurnakan kemampuan berbiacara peserta didik yang memperoleh hasil $84,77 \%$. Hal ini membuktikan bahwa metode bermain peran dpat meningkatkan kemampuan berbicara peserta didik.

Berdasarkan hasil penelitian dan kesimpulan di atas, ada beberapa saran yang peneliti ingin sampaikan, anatara lain sebagai berikut :

a. Bagi Guru

Alangkah baiknya jika guru dapat menerapkan metode pembelajaran yang lebih variatif lagi agar para peserta didik menjadi lebih aktif dan semangat dalam mengikuti pembelajaran dan dapat meningkatkan kemampusan serta hasil belajar peserta didik agar menjadi lebih baik. Dan untuk metode bermain peran dapat digunakan pada pembelajaran selanjutnya karena dapat meningkatkan kemampuan berbicara peserta didik.

b. Bagi Peserta Didik

Peserta didik sebaiknya dapat lebih semangat dan bermotivasi dalam mengikuti pembelajaran dan melatih mental mereka agar berani untuk maju kedepan kelas maupun menyampaikan pendapat atau bertanya kepada guru jika ada hal yang kurang dipahami selama proses pembelajaran berlangsung.

c. Bagi Pembaca

Penelitian ini dapat dijadikan salah satu referensi jika nantinya akan meneliti dengan model pembelajaran yang sama. Atau dapat memngembangkan metode pembelajaran lainnya untuk dapat menumbuhkan semangat belajar bagi para peserta didik.

\section{Daftar Rujukan}

Anas, Sudijono. 2008. Pengantar Evaluasi Pendidikan. Jakarta: Raja GrafindoPersada.

Arikunto, Suharsimi. 2012. Dasar-dasar evaluasi pendidikan edisi 2. Jakarta : Bumi Aksara.

Depdikbud. 1995/1996. Petunjuk Peningkatan Mutu Pendidikan di Sekolah Dasar. Jakarta: Depdikbud.

Febrisma, N., 2013. Upaya Meningkatkan Kosakata Melalui Metode Bermain Peran Pada Anak Tunagrahita Ringan (PTK kelas DV di SLB Kartini Batam). E-JUPEKhu (Jurnal Ilmiah Pendidikan Khusus), 1, pp.2120.

Haryadi dan Zamzami. (1996/1997). Peningkatan Keterampilan Berbahasa Indonesia. Jakarta : Dirjen Dikti.

Kencana, Wayan Nur. 2008 Evaluasi Pendidikan. Surabaya: PT Usaha Nasional.

Ngatiyo, dkk. 2013. Penerapan Metode Bermain Peran pada Pembelajaran IPS untuk Meningkatkan Hasil Belajar Peserta didik Kelas IV. Pontianak: Universitas Tanjungpura.

Ningsih, S., 2014. Peningkatan Keterampilan Berbicara Melalui Metode Bercerita Siswa Kelas III SD Negeri 1 Beringin Jaya Kecamatan Bumi Raya Kabupaten Morowali. Jurnal Kreatif Tadulako, 2(4).

Permendiknas No. 41 Tahun 2007. standar proses. Jakarta. Permendiknas.

Pranowo, D.J., 2013. Implementasi Pendidikan Karakter Kepedulian dan Kerja Sama pada Mata Kuliah Keterampilan Berbicara Bahasa Prancis dengan Metode Bermain Peran. Jurnal Pendidikan Karakter, 2(2).

Purwo, Bambang Kaswanti. 1990. Pragmatik dan Pengajaran Bahasa: Menyibak Kurikulum 1984. Yogyakarta: Kanisius.

Reinny, Leinna Mega 2012. Peningkatan Hasil Belajar Matematika Pembagian Dua Angka Melalui Metode Bermain Peran. Salatiga: Universitas Kristen Satya Wacana. 
Rosnita dkk. 2013. Peningkatan aktivitas pembelajaran Ilmu Pengetahuan Sosial dalam metode Bermain Peran. Pontianak: universitas tanjungpura.

Siregar, Sofyan. 2011. Statistika Deskriptif Untuk Penelitian. Jakarta: PT Raja Grafindo Persada.

Siska, Y., 2011. Penerapan metode bermain peran (role playing) dalam meningkatkan keterampilan sosial dan keterampilan berbicara anak usia dini. J. Educ, 1(1).

Supardi dan Suhardjono. 2015. Penelitian tindakan kelas / Suharsimi Arikunto, Suhardjono, Supardi ; editor, Suryani. Jakarta: Bumi Aksara.

Syamsuddin, A.R. 1986. Sanggar Bahasa Indonesia. Jakarta: Universitas Terbuka Jakarta.

Tarigan, Henry. 1986. Menyimak Sebagai Suatu Keterampilan Berbahasa. Bandung: Angkasa.

Tarigan. 1991. Metodologi Pengajaran Bahasa. Bandung: Angkasa.

Undang-Undang Sistem Pendidikan Nasional No. 20 Tahun 2003.

Wicaksono, G., 2013. Penerapan teknik bermain peran dalam bimbingan kelompok untuk meningkatkan kemampuan komunikasi interpersonal siswa kelas X multimedia SMK IKIP Surabaya. Jurnal BK UNESA, 1(1).

Wijana, I Dewa Putu. 1996. Dasar-dasar Pragmatik. Yogyakarta: Andi.

Yule, George. 2006. Pragmatik. Yogyakarta: Pustaka Pelajar. 